\title{
Марія КАЗЬМИРЧУК
}

докторка історичних наук, професорка,

доцентка кафедри етнології та краєзнавства,

Київський національний університет ім. Т.Шевченка

(Київ, Україна), brungilda@ukr.net

ORCID: https://orcid.org/oooo-oooI-8877-4489

\section{Наталія МЕX}

докторка філологічних наук, професорка,

провідна наукова співробітниця,

Інститут мистецтвознавства, фольклористики

та етнології ім. М.Рильського НАН України,

Український етнологічний центр,

(Київ, Україна), mno_logos@ukr.net

ORCID: https://orcid.org/oooo-ooo2-5846-505X

\section{Маєткова культура України у сучасних гуманітарних та природничих дослідженнях}

DOI: https://doi.org/10.15407/uhj2021.03.157

УДК: 930:94(477):727]《19/20»

\begin{abstract}
Анотація. Метою дослідження $є$ аналіз сучасних праць представників гуманітарних та природничих наук щодо висвітлення маєткової культури України кінця XVIII - початку XIX ст. Методологія. У статті використано загальнонаукові принципи, метод історіографічного аналізу та проблемно-хронологічний метод. Наукова новизна. Стан дослідження маєткової культури України мистецтвознавчого та природничого напрямку нині не висвітлений. Висновки. Мистецтвознавчий напрям досліджень маєткової культури України, так само як у радянський період, понині залишається одним з найкраще представлених. Дослідження щодо архітектури маєтків торкаються біографій видатних зодчих, проблем вивчення стильового образу маєтків, а садово-паркові комплекси розглядаються як твори мистецтва, зокрема аналізуються форми та композиція в парковому мистецтві, висвітлюються принципи садово-паркового будівництва. Велику увагу мистецтвознавці та культурологи традиційно приділяють будівлям маєтків, інтер'єрам, декору та мистецьким колекціям. Архітектори переважно аналізують стилі маєткового будівництва та складають авторську періодизацію. Слід відзначити, що більшість праць архітектурного напряму наближені до історико-краєзнавчого напрямку. Природничий напрямок представлений насамперед працями географів (історична та фізична географія, етнокультурне та антропогенне ландшафтознавство) та біологів (ботанічні аспекти садово-паркових комплексів). Представники цього напрямку переважно акцентують увагу на садово-паркових ландшафтах, їхній дендрофлорі. Сучасні праці вітчизняних дослідників сприяють поглибленню історикоархітектурних та природничих знань щодо маєткової культури України та залученню до наукового обігу низки втрачених пам'яток палацової та садибно-паркової архітектури різних регіонів, що надає можливість створити цілісну історію розвитку маєтків та їхнього культурного світу нашої держави.
\end{abstract}

Ключові слова: маєтки-садиби, замки, вілли, реставрація, пам'ятка архітектури, відновлення, ландшафтний комплекс. 
Маєткова культура України стала об’єктом досліджень мистецтвознавців з самого початку іï наукового вивчення на рубежі XIX-XX ст. Старовинні українські маєтки та садибно-паркові комплекси привертали увагу не одного покоління дослідників. Навіть за радянського періоду їхнє дослідження не припинилося, а навпаки праць присвячених маєткам стало набагато більше. Ця міждисциплінарна проблема й понині цікавить багатьох науковців, зокрема біологів, географів, культурологів, архітекторів та архітектурознавців, які взялися з новими методами за грунтовний аналіз усіх iї мистецьких аспектів. Сучасних підходів накопичилося достатньо аби зробити окремий історіографічний аналіз гуманітарного та природничого блоку досліджень маєткової культури України кінця XVIII - початку XX ст. На жаль, історико-краєзнавчі дослідження, які нині складають велику кількість різних напрямів та підходів, неможливо розглянути в одній статті єдиним гуманітарним блоком, а отже, вони залишаються проблемою на перспективу.

Новітня історіографія маєткової культури України мистецтвознавчого та природничого напрямку на сьогодні загалом непроаналізована. Слід відзначити окрему статтю архітекторки Л.Шевченко щодо історіографічного вивчення досліджень палацово-паркового будівництва Полтавщини у XVIII-XIX ст.' У праці мистецтвознавця В.Халайцана, присвяченій джерелам з мистецтва паркобудування, міститься історіографічний аналіз цілого масиву праць мистецтвознавчого напряму щодо дослідження маєткових парків². Історію досліджень культурної спадщини поляків на Поділлі висвітлив географ В.Воловик. Праці декількох сучасних дослідників мистецтвознавчого напрямку згадує як спеціальну літературу з проблем вивчення культурно-мистецької спадщини Волині кінця XVIII - початку XIX ст. Т.Смирнова ${ }^{4}$. Праці деяких сучасних дослідників аматорської музично-театральної культури України аналізує О.Матола5. Більшість історіографічних праць щодо архітектури маєтків та маєткових парків є досить описовими, не містять жодних зауважень, представлені у вигляді коротких анотацій та переліку прізвищ у певному хронологічному порядку. Проте загалом порушені дослідниками проблеми є актуальними та доводять зростання інтересу до вивчення маєткової культури України представниками мистецтвознавчого і природничого напрямів.

Маєтки України - це не звичайні історико-культурні пам'ятки, а складні комплекси, що поєднують архітектурні та природні елементи. Це різні споруди: житлові, службові, господарські та промислові, а також парки та сади, ставки та озера, крім того й малі архітектурні форми, оформлені відповідно до панування певного стилю. Тому вони привертають увагу не тільки істориків та краєзнавців, але й мистецтвознавців, архітекторів, ландшафтних дизайнерів, географів та біологів.

Мистецтвознавчі праці щодо маєткової культури України доцільно поділити на такі дослідницькі напрямки: архітектура маєтків, археологічна екологія та проблеми збереження маєткової спадщини, паркове мистецтво маєтків, мистецькі колекції та художнє мистецтво маєтків, музичне та театральне мистецтво маєтків.

\footnotetext{
1 Шевченко Л.С. Палацово-паркове будівництво на Полтавщині у XVIII-XIX ст.: історіографічний аспект // Українська академія мистецтва: Дослідницькі та науково-методичні праці. - Вип.8. - К., 2001. - С.211-217.

2 Халайщан В.П. Мистецтво маєткового паркобудування Поділля XVIII - початку XX ст.: еволюція дослідницької традиції // Вісник Львівської національної академії мистецтв. - Вип.34. - Л., 2017. - С.101.

3 Воловик B. Історія дослідження польської етнокультури у містечках Поділля // Історія української географії. Вип.23. - Тернопіль, 2011. - С.32-36.

${ }^{4}$ Смирнова T.B. Проблеми вивчення культурної спадщини Волині кінця XVIII - початку XIX ст. у спеціальній літературі // Українська культура: минуле, сучасне, шляхи розвитку. - Вип.18(2). - Рівне, 2012. - С.44.

5 Mатола О.О. Аматорська музично-театральна культура України: історіографія дослідження // Вісник КНУКіМ: Серія «Мистецтвознавство». - Вип.3. - К., 2014. - С.62-68.
} 
Серед дослідників архітектури маєтків, біографій видатних архітекторів та їхніх творінь, слід відзначити праці І. та О.Родічкиних, В.Тимофієнка, В.Вечерського, О.Михайлишин, Н.Левкович, Л.Шевченко, В.Смоляка, О.Хорошої, В.Маланюк.

Доктор архітектури та ландшафтний архітектор I.Родічкін, автор проектів створення та відновлення національних і садибних парків, зокрема відновлення садиби Качанівка. На початку г990-х рр. він підготував та опублікував багаторічну працю 3 історії маєтків, яка вважається енциклопедією маєткового будівництва і садово-паркового мистецтва України. У 2005 р. праця «Старовинні маєтки України» була перевидана за участю О.Родічкіної. Це дуже гарно ілюстроване видання демонструє фотокопії з архівів, музеїв та приватних зібрань, містить історичний екскурс у маєткову архітектуру палаців та парків. Крім історичних відомостей, описів та планів палацово-паркових ансамблів, наводиться характеристика діяльності відомих маєткових архітекторів, зокрема О.Паліцина й Д.Міклера, висвітлюється паркобудівнича та пейзажна майстерність у садово-парковому мистецтві України. Цінним є зібраний матеріал щодо маєтків, що майже не збереглися до нашого часу. Містить мемуарні джерела, архівні дослідження та поетичні рядки. Назви маєтків та надписи до фотографій перекладені англійською мовою, що дає можливість віднести працю до жанру путівників ${ }^{6}$.

Особливості маєткової архітектури періоду класицизму й ампіру на українських теренах досліджував архітектурознавець та мистецтвознавець В.Тимофієнко. Він зібрав біографічні дані видатних архітекторів, які працювали в Україні, зокрема архітекторів маєтків. Виділяється постать маєткового архітектора Д.Міклера та дається перелік його творінь - пейзажних парків. Дослідник нараховує близько зо його парків на Волині, Поділлі. Також В.Тимофієнко висвітлює творчість Д.Мерліні - майстра класицизму і творця палацово-паркових ансамблів України, та О.Паліцина - будівничого парків, архітектора, поета, перекладача, педагога. Загалом ця праця має енциклопедичний характер, адже персоналії складено у алфавітному порядку, а інформація лаконічна і стисла. Проте сам автор праці вказує на можливі неточності та ії незавершеність, адже чимало інформації потребує перевірки та доопрацювання, зокрема ініціали архітекторів або пам'ятки архітектури невідомих архітекторів, переліком яких можуть поповнитися біографічні відомості творців маєтків. У передмові головний архітектор Києва С.Бабушкін відзначає: «Поняття зодчі в даному контексті включає в себе не тільки архітекторів, а й інженерів, народних будівничих, майстрів садово-паркового мистецтва, скульпторів-монументалістів, які встановлювали пам'ятники або оздоблювали споруди статуями і рельєфами, тобто мова йде про всіх творців того життєвого простору, в якому реально існує людина, котре безпосередньо і щоденно впливає на світосприйняття суспільства визначає менталітет народу, формує національну свідомість громади тощо» ${ }^{7}$.

В.Тимофієнко у співавторстві з В.Єрошевим видрукував брошуру щодо української маєткової архітектури другої половини XVIII - першої третини XIX ст. Автори опрацювали значний масив інформації щодо історії маєткової архітектури та висвітлили еволюцію маєткового будівництва України, навели багато ілюстративного матеріалу, реконструкцій і планів-схем ${ }^{8}$.

Архітектор та мистецтвознавець В.Вечерський має ряд праць про маєтки. Він автор науково-популярного видання та науково-публіцистичних праць про замки й

\footnotetext{
Родічкін І.Д., Родічкіна О.І. Старовинні маєтки України: Книга-альбом. - К., 2005. - 384 с.

Тимофієнко B.I. Зодчі України кінця XVIII - початку XX ст.: біографічний довідник. - К., 1999. - 475 с.

8 Тимобієнко B.I., Єромев В.Ю. Українська садибна архітектура другої половини XVШ ст. - першої третини XIX ст. K., 1993. - $44 \mathrm{c}$.

' Вечерський В.В. Замки та фортеці України. - К., 2015. - 152 с.
} 
палаци Закарпаття, зокрема маєтки Шенборнів, Чинадіївський замок барона Перені ${ }^{\text {, }}$ а також про архітектурну спадщину Полтавщини, зокрема маєтки Котляревських у Вишняках та палац у Березовій Рудці під Пирятином".

Історичні передумови розвитку, композицію та стилістику палацово-паркового будівництва Волині другої половини XVIII-XIX ст. досліджує архітекторка О.Михайлишин. Вона висвітлює також особливості утворення маєтків волинської шляхти ${ }^{12}$.

Архітектурно-стилістичні особливості палацових та садибно-паркових ансамблів Галичини кінця XVIII - першої половини XIX ст. досліджує мистецтвознавиця Н.Левкович. Авторка підкреслює роль маєтків Галичини у формуванні художніх особливостей архітектури регіону, естетичних вподобань тогочасного суспільства, у домінуванні принципу класицизму та загалом у творенні феномену маєткової культури ${ }^{13}$. Дослідниця виділяє три періоди в розвитку архітектури класицизму на Галичині: початок XVIII ст., третя чверть XVIII ст., кінець XVIII ст. ${ }^{14}$

Розвиток палацово-паркових ансамблів Полтавщини XVIII-XIX ст. досліджує архітекторка Л.Шевченко. Ї̈̈ увага зосереджується як на загальних тенденціях маєткового архітектурного будівництва Полтавщини, так і на окремих маєтках регіону. Так, вона проаналізувала визначальні соціально-економічні та історичні передумови створення маєткових комплексів ${ }^{15}$, представила періодизацію палацово-паркового будівництва та визначила канони маєткового паркобудування Полтавського регіону ${ }^{16}$. Вона дослідила особливості маєтку Кочубеїв у Диканьці та дворянське гніздо МуравйовихАпостолів, де подає дуже багато історичного матеріалуㄱ. Крім того, слід відзначити, що саме Л.Шевченко, досліджуючи особняки Полтави, дає визначення терміна «особняк» ${ }^{18}$.

Розвиток маєткової архітектури та маєтки стилю класицизм Східного Поділля досліджують архітектори О.Хороша та В.Смоляк. У співавторстві вони проаналізували особливості формування класицизму як стилю палацової архітектури Східного Поділля, зокрема пам'ятку архітектури кінця XVIII - початку XIX ст. - палац Т.Ланге в с. Нападівка ${ }^{19}$. О.Хороша - авторка низки одноосібних праць щодо розвитку палацової класицистичної архітектури Східного Поділля. Вона висвітлює ряд

\footnotetext{
${ }^{10}$ Вечерський В.В. Пам’ятки Срібної землі // Українська культура. - 2014. - №5(1025). - С.5, 22.

${ }^{11}$ Вечерський В.В. Архітектурна спадщина Полтавщини // Там само. - №6(1026). - С.31.

${ }_{12}$ Михайлищин О.Л. Палацово-паркові ансамблі Волині 2-ї половини XVIII-XIX ст. - К., 2000. - 234 с.

${ }_{13}$ Левкович Н.Я. Палацові та садибно-паркові ансамблі Галичини епохи класицизму: До питання періодизації // Народознавчі зошити. - Зош.5. - Л., 2000. - С.900-905.

14 Левкович Н.Я. Палацові та садибно-паркові ансамблі Галичини кінця XVIII - першої половини XIX ст.: До питання побудови ансамблю // Вісник НУ «Львівська політехніка»: Архітектура. - Вип.439. - Л., 2002. - С.246-250.

${ }^{15}$ Шевченко Л.С. Історичні передумови розвитку палацово-паркового будівництва на Полтавщині у XVIII-XIX ст. // Археологічний літопис Лівобережної України. - Вип.1. - Полтава, 2002. - С.39-41.

${ }_{16}$ Шевченко Л. Старовинні присадибні парки Полтавщини як своєрідна форма синтезу мистецтв // Проблеми розвитку міського середовища. - Вип.1. - К., 2016. - С.144-151.

${ }_{17}$ Шевченко Л.С. Палацово-паркове будівництво на Полтавщині у XVIII-XIX ст.: історіографічний аспект // Українська академія мистецтва: Дослідницькі та науково-методичні праці. - Вип.8. - К., 2001. - С.211-217; Ï̈ ж. Особливості формування палацово-паркового ансамблю Кочубеїв у Диканьці // Там само. - Вип.17. - К., 2010. С.172-183; Ï ж. Дворянське гніздо Муравйових-Апостолів на Полтавщині // Полтава: архітектура, історія, мистецтво: Мат. II наук. конф. «Вайнгортівські читання», грудень 2003 р. - Полтава, 2003. - С.33-39.

${ }^{18}$ Шевченко Л.С. Старовинні особняки Полтави та їх значення в архітектурному розвиткові міста // Полтава: архітектура, історія, мистецтво: Мат. III наук. конф. «Вайнгортівські читання», грудень 2009 р. - Полтава, 2009. C.35.

${ }^{19}$ Смоляк B.B., Хорома O.I. Дослідження пам'ятки архітектури кінця XVIII - початку XIX ст. - палацу Тора Ланге в селі Нападівка, Липовецького району, Вінницької області // Сучасні проблеми архітектури та містобудування. Вип.40. - К., 2015. - С.137-145; İ же. Історико-архітектурні особливості розвитку палаців стилю класицизм Східного Поділля кінця XVIII - початку XX ст. // Вісник Національного університету «Львівська політехніка»: Архітектура. Вип.878. - Л., 2017. - С.50-58.
} 
історико-архітектурних особливостей Чорноминського палацу XIX ст., історію архітектури та сучасний стан маєтку Грохольських-Можайських, а також ландшафтну архітектуру парків палацово-паркових комплексів Вінниччини стилю класицизм кінця XVIII - початку XX ст. ${ }^{20}$ Дослідниця представила науковому загалу типологію палацово-паркового будівництва, відзначаючи найдрібнішим його щаблем садиби, а найбільшим - палацово-паркові ансамблі ${ }^{21}$.

Особливості композиції у будівництві палацових та садибно-паркових ансамблів Київщини кінця XVIII - XIX ст. досліджує архітекторка В.Меланюк. Так, у статті вона визначила відмінності регіональної садибної архітектури, проаналізувала внесок архітекторів та паркобудівничих у розвиток садибно-паркових утворень, висвітлила періоди та основні репрезентативні садиби Київської губерніі. Наголошуючи на потребі історико-архітектурного дослідження, вона використовує терміни «садибно-паркові утворення» та «класицистичні садибні комплекси» без їх тлумачення ${ }^{22}$.

Напрям археологічної екології та проблем збереження маєткової спадщини представлений працями І.Смолинця, А.Магей, Т.Никоненка, Л.Гнатюка, О.Бойка, І.Пограничної.

На пам’яткоохоронну справу маєтків і палаців Західної України, проблеми їх автентичного відновлення та утримання звернув увагу мистецтвознавець В.Смолинець. Він наводить визначення маєтку як «садиби, володіння знатних людей (дворян, старшин, шляхти, купців) і заможних представників інших класів, періоду XVII - початку XX ст.». Дослідник визначає основні категорії сучасних збережених українських маєтків та склад класичного маєтку-садиби ${ }^{23}$. Найкращим рішенням щодо захисту сучасних маєткових комплексів від руйнування В.Смолинець вважає їхню повну або часткову музеєфікацію, передачу в приватну власність із контролем держави або фондів ${ }^{24}$.

Архітекторка А.Магей указала на теоретичні можливості реконструкції неоготичного маєтку Щеньовських у с. Капустяни Вінницької обл. Поряд з історичними відомостями про село та маєток, подано авторську план-схему ділянки маєтку, його графічну реконструкцію. Крім того, методом аналогій реконструйовано його внутрішнє середовище ${ }^{25}$.

Реконструкцією маєтку Д.Трощинського в Кагарлику на Київщині за допомогою філософської концепції «екології душі» здійснили мистецтвознавці Т.Никоненко та Л.Гнатюк. Вони наголошують, що розквіт маєткової культури України припадає на кінець XVIII - початок XIX ст., а характерною рисою цієї культури була «своєрідна синтетичність, що втілювалася у взаємозв'язках пластичних мистецтв (садово-паркового, образотворчого, архітектури) та видовищних (театрального, музичного)»²6. Автори

\footnotetext{
${ }^{20}$ Хорома O.I. Розвиток палацової архітектури стилю класицизм на Східному Поділлі // Сучасні проблеми архітектури та містобудування. - Вип.50. - К., 2018. - С.88-98; Ї̈ $⿻$. Дослідження історико-архітектурних особливостей Чорноминського палацу ХІХ ст. Східного Поділля // Науковий вісник будівництва. - Вип.2. - Х., 2016. - С.94-98. Ii $\mathscr{K}$. Маєток Грохольських-Можайських - еволюція палацу від історичного становлення до сучасної реставрації // Там само. - Т.89. - №3. - Х., 2017. - С.33-38; Ї̈ ж. Принципи планування парків палацово-паркових комплексів Вінниччини стилю класицизм кінця XVIII - початку XX ст. // Сучасні проблеми архітектури та містобудування. Вип.53. - К., 2019. - С.73-80.

${ }^{21}$ Хороша О.І. Розвиток палацової архітектури стилю класицизм на Східному Поділлі. - С.90.

${ }_{22}$ Маланюк B.Я. Розвиток класицистичних садибно-паркових утворень Київщини кінця XVIII-XIX ст. // Вісник Національного університету «Львівська політехніка»: Архітектура. - Вип.568. - Л., 2006. - С.272.

${ }_{23}$ Смолинещъ В. Утримання та відновлення кращих взірців маєтків та палаців Західної України // Вісник Львівського національного аграрного університету: Серія «Архітектура і сільськогосподарське будівництво». - Вип.19. - Л., 2018. - С.152.

${ }_{24}$ Там само. - С.151-153.

${ }^{25}$ Магей A.C. Неоготична садиба в селі Капустяни Вінницької області: спроба гіпотетичної реконструкції // Сучасні проблеми архітектури та містобудування. - Вип.55. - К., 2019. - С.102, 106.

${ }^{26}$ Никоненко T.М., Гнатюк Л.Р. До питання реконструкції палацо-паркового ансамблю Д.Трощинського в Кагарлику на Київщині на засадах філософської концепції «екології душі» // Сучасні проблеми архітектури та містобудування. Вип.23. - К., 2010. - С.63.
} 
статті звертають увагу на жалюгідне нинішнє становище заснованого Д.Трощинським Кагарлицького парку - пам’ятки садово-паркового мистецтва. Вони закликають до актуалізації маєткового досвіду національного спілкування з природними об'єктами та популяризації високої культури екології душі на державному рівні ${ }^{27}$.

Пропозиції реставрації маєтків на Волині, творцем яких був Я.Кубіцький, запропонували у спільній статті архітектори О.Бойко та І.Погранична. Вони визначили особливості архітектури палацових комплексів Я.Кубіцького за допомогою іконографічних та картографічних джерел, а також в результаті власних обстежень. Дослідники запропонували авторську програму збереження, консервації та реставрації палацово-паркового ансамблю у с. Самчики Хмельницької обл. У статті мистецтвознавці широко використовують терміни «резиденція», «маєток», «садиба», «фільварок» як синоніми. Проте інколи садиба розглядається ними як частина маєтку, а термін «резиденція» використовується у визначенні замку та загалом господарської системи ${ }^{28}$. Дискусійним є твердження, що «наприкінці XVIII - на початку XIX ст. почало розвиватися містобудування в селі, де зводилися магнатські резиденції, шляхетські садиби, фільваркові і господарські будівлі» ${ }^{29}$. І.Погранична дослідила втрачені палацові будівлі Я.Кубіцького та палацовий комплекс у Самчиках як приклад європейської архітектури стилю класицизм ${ }^{30}$.

Дуже актуальним та активно досліджуваним сьогодні $є$ напрям паркового мистецтва маєтків, представлений працями Н.Соснової, В.Халайцана, О.Любченко, П.Ричкова, Н.Лушнікової, Н.Ковальчука.

Грунтовне дослідження ландшафтного мистецтва палацових та садибно-паркових ансамблів Галичини кінця XVIII - першої половини XIX ст. провела архітекторка Н.Соснова. Вона детально аналізує ландшафтні особливості, майже не звертаючи увагу на стильові та архітектурні властивості палацових ансамблів і маєтків. Н.Соснова висвітлила вплив австрійської колонізації, розробила типологію та представила планувальні структури садибно-паркових комплексів Галичини ${ }^{31}$.

Мистецтвознавець В.Халайцан досліджує ландшафтний дизайн і проектування території палацово-паркових комплексів Поділля XVIII - початку XX ст., зокрема відзначаючи внесок ландшафтних архітекторів маєткових парків. На його думку, мистецтво паркобудування - це унікальний, мультикультурний і мультинауковий мистецький феномен, який вивчається у рамках історичного, архітектурного та мистецтвознавчого напрямків. Він розробив періодизацію та виділив три основні періоди у дослідженнях мистецького феномену маєткового парку. Проте деякі з чотирьох основних груп матеріалів, відзначені В.Халацаном, не були достатньо розглянуті, зокрема фотодокументи та літературні джерела ${ }^{32}$. В іншій статті дослідник звертає увагу

\footnotetext{
${ }_{27}$ Там само. - C.65-66.

${ }^{28}$ Бойко О.Г., Погранична I.I. Палацово-паркові ансамблі Якуба Кубіцького на Волині: Архітектурні особливості, пропозиції до реставрації // Вісник Національного університету «Львівська політехніка»: Архітектура. - Вип.816. Л., 2015. - С.178-179.

${ }^{29}$ Бойко О.Г., Погранична I.I. Палацово-паркові ансамблі Якуба Кубіцького на Волині... - С.178.

${ }^{30}$ Погранична I.I. Палацовий комплекс у с. Самчиках Хмельницької обл. - приклад класицистичної європейської архітектури кінця XVIII - початку XIX ст. // Вісник Національного університету «Львівська політехніка»: Архітектура. - Вип.856. - Л., 2016. - С.186-190; Ї̈ ж. Втрачені палацові комплекси авторства Якуба Кубицького на території України // Архітектурний вісник КНУБА. - Вип.10. - К., 2016. - С.236-242.

${ }^{31}$ Соснова Н.С. Типологія садибно-паркових комплексів Галичини к. XVIII ст. // Вісник Державного університету «Львівська політехніка»: Архітектура. - Вип.358. - Л., 1998. - С.285-290; П̈і ж. Вплив австрійської колонізації Галичини на розвиток садибно-паркових комплексів // Німецькі колонії Галичини: історія, архітектура, культура. - Л., 1996. - С.342-347; $\dddot{I} i \dddot{*}$. Інформативність кадастрових карт (До питання вивчення планувальних структур садибнопаркових комплексів Галичини сер. ХIX ст.) // Картографія та історія України. - Л.; К.; Нью-Йорк, 2000. - С.252-258. ${ }_{22}$ Халайщан В.П. Мистецтво маєткового паркобудування Поділля XVIII - початку XX ст.: еволюція дослідницької традиції // Вісник Львівської національної академії мистецтв. - Вип.34. - Л., 2017. - С.90, 92-93.
} 
на найцікавіші садово-паркові комплекси як об’єкти культурної спадщини (будинки та садиби), що залишилися у селах Ярмолинецького р-ну Хмельницької обл. Висвітлює також історію та сучасний стан палаців Куявського й Маровського ${ }^{33}$.

Маєткові парки як дозвіллєво-розважальну складову європейської культури досліджує культурологиня О.Любченко. У статтях вона проводить досить широке дослідження дозвілля у парках - від часів Давньої Греції до сучасності, але чимало уваги приділяє маєтковим паркам України другої половини XVIII - початку XIX ст. Окремо акцентує увагу на формуванні розважального простору приватних парків у заміських резиденціях дворянства й аристократії Російської імперії ${ }^{34}$

Особливості застосування водних елементів у створених ландшафтних композицій садівничим Д.Міклером на Волині у XIX ст. висвітлюють архітектори П.Ричков та Н.Лушнікова. Вони підкреслюють, що постать Д.Міклера дуже актуальна, адже саме він утілював англійський пейзажний садовий стиль у цьому регіоні, бездоганно об'єднуючи мальовничі природні та штучні водні компоненти у садовій структурі маєтків. Фахівці також наводять приклади його творінь - резиденції польських поміщиків у Городку, Мізочі, Млинові, Шпанові 35 . Також П.Ричков окремо дослідив палацово-паркове мистецтво в історії архітектури волинського м. Рівне другої половини XVIII ст., що розвивалося під патронатом магнатів Любомирських та за безпосередньої участі архітектора Ж.Бургіньйона. Він використовує карту їхньої резиденції I797 р., що дає можливість відтворити детальний опис палацового паркуз

Садово-паркове мистецтво в маєтках Луцька досліджує спеціалістка у сфері сільського господарства Н.Ковальчук. Вона виділяє особливості волинських «садів у мурах» та порівнює видовий склад дендрофлори у старовинних маєткових парках із сучасними приватними садами ${ }^{37}$.

Активно досліджуються впродовж тривалого періоду мистецькі колекції та художнє мистецтво маєтків у працях Н.Гасанової, С.Курач, В.Рубан, С.Побожія. Чимало студій цього напряму присвячено мистецьким художнім колекціям окремих знаних родин, зокрема Галаганів.

Мистецтвознавиця Н.Гасанова-Тарковська дослідила художній світ маєтку прилуцького полковника П.Галагана у Сокиринцях на Чернігівщині. Вона звертає увагу на архітектуру, ландшафтний дизайн парку, інтер'єр та оздоблення палацу Галаганів різних періодів, висвітлює біографії власників ${ }^{38}$. Мистецькі колекції та фамільну галерею галаганівського маєтку у Сокиринцях дослідила мистецтвознавиця С.Курач 39 .

В.Рубан активно працювала над українським портретним живописом, зокрема портретами XVIII-XIX ст., та визначними мистецькими родинами України. В ії праці висвітлюються художні смаки родини Галаганів, історія підтримки ними митців і внесок знаних династій у розвиток національної художньої культури ${ }^{40}$.

\footnotetext{
${ }_{33}$ Халайщан В.П. Палацово-паркові комплекси Ярмолинеччини XIX - початку XX ст.: історія, проблеми // Хмельницькі краєзнавчі студії. - Вип.5. - Хмельницький, 2015. - С.212-218.

${ }^{34}$ Любченко О.М. Архітектурно-композиційне формування паркового простору: принципові підходи // Українська культура: минуле, сучасне, шляхи розвитку. - Вип.21. - Т.2. - Рівне, 2015. - С.128-129.

${ }^{35}$ Rychkov P., Lushnikova N. Natural materiality: water as an active element of the gardens by Denis Mcclair at Volhynia // Teka Komisii Architektury, Urbanistyki i Studiów Kraiobrazowych. - 2015. - №2. - C.52-62.

${ }^{36}$ Rychkov P. Zespół pałacowo-ogrodowy Lubomirskich w Równem w świetle planu Iana Iakuba Bourguignona z 1797 r. // Biuletyn Historii Sztuki. - T.72. - №3. - Warszawa, 2010. - S.335-349.

${ }^{37}$ Ковальчук Н.П. Садово-паркове мистецтво у приватних садах м. Луцька // Науковий вісник НЛТУ України. Вип.3. - Л., 2006. - С.20.

${ }^{38}$ Гассанова Н. Палац у Сокиринцях // Народна творчість та етнографія. - 1994. - №2/3. - С.64-70.

${ }^{39}$ Курач С.М. Колекція творів мистецтва Галаганів // Сіверянський літопис. - 1995. - №5. - С.60-63.

${ }_{40}$ Рубан В.В. Художники і сімейство Галаганів. - Срібне, 2010. - 88 с.
} 
С.Побожій аналізує становище маєтків та маєткових колекцій Слобожанщини на початку XX ст., а також діяльність щодо їх порятунку харківськими мистецтвознавцями. Чимало уваги дослідник приділяє діяльності професора Харківського університету Є.Редіна, зокрема щодо організації ним екскурсії до маєтку Харитоненків в Охтирському повіті ${ }^{41}$, а також фотографа університетського музею Б.Руднєва, який допомагав збирати та рятувати від нищення мистецькі колекції маєтків Лебединщини на початку XX ст. ${ }^{42}$ С.Побожій висвітлює художнє мистецтво маєтків і формування художніх колекцій знаних родин Сумщини як соціокультурний феномен ${ }^{43}$. Також чимало статей дослідника присвячено біографіям видатних художників, які так або інакше причетні до творення маєткового мистецтва ${ }^{44}$.

Вивчення музичного й театрального мистецтва маєтків активізується завдяки працям Н.Чечель, О.Ізваріної, Л.Кохан, О.Волосатих, Т.Публіки, М.Антошко, О.Матоли, В.Богданова, А.Сікорської.

Український романтичний театр першої половини XIX ст., його репертуар, постановочні засоби, манеру виконання таких акторів-кріпаків як М.Щепкін та К.Соленик, характеристику тогочасних глядачів висвітлює мистецтвознавиця Н.Чечель. В їі праці аналізується соціально-політична атмосфера, притаманна українському соціуму, який поступово крокував до національного самоусвідомлення й самореалізації ${ }^{45}$.

Маєткову культуру, музичний побут, кріпацький та аматорський театри в магнатських маєтках досліджує О.Ізваріна. Вона узагальнює інформацію щодо музичного побуту першої половини XIX ст., що стане основою українського оперного мистецтва, де поєднуються музичне та драматичне начало ${ }^{46}$.

Маєткове мистецтво і приватну антрепризу, а також їх роль у становленні українського професійного театру другої половини XVIII - першої половини XIX ст. досліджує мистецтвознавиця Л.Кохан. В їі статті виділяються як позитивні, так і негативні чинники впливу володарів маєтків на розвиток театрального мистецтва, висвітлюються етапи формування театрального репертуару, характеризується професійна підготовка акторів, композиторів та інструменталістів. Вона наголошує на відмінностях і неоднорідності культурного життя панських маєтків ${ }^{47}$.

Музичну й театральну культуру, оперне та театральне мистецтво в маєтках Правобережної України першої половини XIX ст. досліджує О.Волосатих. Вона здійснила глибокий аналіз музичного мистецтва Поділля, висвітлила специфічні риси маєткового театру, поділяючи його на магнатський, аматорський та антрепренерський, а також описуючи його становище в окремих маєтках Правобережжя першої половини XIX ст. ${ }^{48}$

${ }^{41}$ Побожій С.I. 3 історії українського мистецтва. - Суми, 2005. - С.47, 162.

${ }^{42}$ Там само. - C. 165 .

43 Побожій С.I. Приватні колекції як соціокультурний феномен // Сучасна картина світу: природа, суспільство, людина. - Суми, 2008. - С.274-278.

${ }^{44}$ Побожій С.I. Олексій Красовський: Матеріали до біографії художника // Сумський історико-архівний журнал. 2009. - №VI-VII. - C.133-140.

45 Чечель Н.П. Український театр першої половини XIX ст. як соціокультурний феномен // Наукові записки НаУКМА. - Т.62. - К., 2007. - С.72.

${ }^{46}$ Ізваріна О.М. Маєткова культура і музичний побут маєтків першої половини ХIX ст. як підгрунтя формування оперного мистецтва в Україні // Культура і сучасність. - Вип.2. - К., 2010. - С.165-169; Ї̈ ж. Кріпацькі та аматорські театри у музичному побуті магнатських маєтків в Україні // Наукові записки Тернопільського національного педагогічного університету ім. Володимира Гнатюка: Серія «Мистецтвознавство». - Вип.2(21). - Тернопіль, 2009. - С.7-12.

${ }^{47}$ Кохан Л.Й. Роль маєткового мистецтва і приватної антрепризи у становленні українського професійного музичнодраматичного театру // Часопис Національної музичної академії України ім. П.І.Чайковського. - Вип.4(41). K., 2018. - C.37.

${ }^{48}$ Волосатих О.Ю. Музична й театральна культура маєтків Правобережної України (перша половина XIX ст.) // Там само. - Вип.4(17). - К., 2012. - С.62-76. 
Музичним мистецтвом панських маєтків Поділля XVIII - початку XIX ст. цікавиться мистецтвознавиця Т.Публіка. В іï праці розглядається професійне музичне середовище маєтків Вінниччини та загалом музичне життя Подільського регіону на рубежі XVIII-XIX ст. Дослідниця розкриває регіональну історію маєткової культури на основі архівних документів ${ }^{49}$.

Театральне мистецтво Подільського краю на рубежі XIX-XX ст. досліджує М.Антошко. Авторка відзначає функціональну універсальність тогочасних театральних колективів, розкриває проблему їхнього репертуару, акцентує увагу на діяльності окремих акторів ${ }^{50}$.

Дослідження різних аспектів аматорського театрального мистецтва, його репертуару та способів реалізації митця в XIX ст. здійснила О.Матола. Ї̈і статті присвячені розвитку театрального мистецтва в межах маєткових салонів та домашнього виконавства кріпацьких аматорських колективів поміщицьких маєтків кінця XVIII - першої половини XIX ст. ${ }^{\text {sI }}$

Історію й діяльність кріпосних оркестрових колективів у маєтках Волинської та Київської губерній другої половини XVIII - першої половини XIX ст. висвітлює мистецтвознавець В.Богданов. Так, детальну характеристику отримали капели Іллінських і Букарів на Волині, Будлянського, Браницьких та фон Мекк на Київщині. Автор відзначає високий професіоналізм кріпосницьких капел попри наявну в них жорстку експлуататорську сутність. Також дослідник підкреслює, що ще досі невідомими залишаються імена музикантів, а ідентифікація відбувається за прізвищами їхніх власників-поміщиків ${ }^{52}$.

Грань між аматорством та професійним музичним мистецтвом у маєткових салонах Російської імперії першої половини XIX ст. розкриває мистецтвознавиця А.Сікорська. В іï праці відзначено особливий культурний побут маєтків, зокрема сімейне та любительське музикування, активна культурна й музична діяльність Маркевичів, Лизогубів, Гаврушкевичів тощо на Чернігівщині, діяльність художньо-музичних салонів Рєпіних і Лукашевичів на Полтавщині, художніх салонів барона Радена й Шидловських на Харківщині ${ }^{33}$. Також дослідниця приділяє увагу постійним музичним салонам Києва, зокрема салону графа Вієльгорського. Вона підкреслює значення маєтків та салонів, місцевих «культурних гнізд» як осередків музичного інтелектуального співтовариства ${ }^{54}$.

Також окремо слід виділити природничий напрям дослідження маєткової культури України, що представлений працями географів і біологів, зокрема В.Воловика, І.Кравцової, Л.Казімірової, О.Кльоца, Т.Курбаль. Дослідники цього напряму, спираючись на властиві географії та біології наукові методи й підходи, звернули увагу на садово-паркову складову маєтків України, адже парки є складовою природних ресурсів.

\footnotetext{
49 Публіка T.В. Розвиток музичного виконавства у панських маєтках на теренах Поділля XVIII - початку XIX ст. // Вісник Прикарпатського університету: Мистецтвознавство. - Вип.XII-XIII. - Івано-Франківськ, 2008. - С.237-240.

${ }^{50}$ Антошко М.О. Театральне життя Подільського краю кінця XIX - початку XX ст. // Вісник Національної академії керівних кадрів культури і мистецтв: Серія «Мистецтвознавство». - Вип.3. - К., 2018. - С.237-238.

${ }^{51}$ Mamoла O.O. Становлення аматорського музичного театру в Україні // Українська культура: минуле, сучасне, шляхи розвитку. - Вип.18(1). - Рівне, 2012. - С.36-40; Ï̈ ж. Діяльність аматорських театральних осередків у культурі України ХIX ст. // Там само. - Вип.18 (2). - Рівне, 2012. - С.73-77.

52 Богданов В.О. Кріпосні капели і оркестри в Україні (на прикладі Волинської і Київської губерній) // Вісник Харківської державної академії дизайну і мистецтв. - Вип.13. - Х., 2008. - С.16.

${ }_{53}$ Сикорская A.B. Любительское музицирование как фактор формирования интеллектуальной культурной среды в царской России первой половины XIX в. // Актуальные проблемы искусствоведения, филологии и культурологии: Мат. междунар. заочной науч.-практ. конф., 18 февраля 2013 г. - Новосибирск, 2013. - С.90-91.

${ }_{54}$ Сикорская $A$. Музыкальная жизнь усадеб и аристократических салонов в процессе формирования профессионализма в музыкальной культуре царской России // Музичне мистецтво і культура: Наук. вісник Одеської державної музичної академії ім. А.В.Нежданової. - Вип.11. - Одеса, 2010. - С.239-247.
} 
Особливості польських етнокультурних ландшафтних комплексів Поділля XVII - початку XX ст. досліджує географ В.Воловик. У його праці відзначено «ядро» житлової частини - «садиба», ландшафтної - «садово-парковий ландшафтний комплекс» та периферії - «фільварок». Він звертає велику увагу на термінологію маєткової культури. В.Воловик, один із небагатьох, дає визначення ключовим поняттям «маєток» і «садиба»55.

Садове мистецтво Правобережжя як одне з найскладніших синтетичних мистецтв та вид архітектурно-художньої творчості вивчає географиня I.Кравцова. Саме садове мистецтво поєднує природу, архітектуру, пластичні мистецтва в композиційний і цілісний витвір. Дослідниця класифікує садово-паркові ландшафти як самостійну групу антропогенних ландшафтів Правобережної України ${ }^{56}$.

Представники біології також досліджують маєткові парки та ландшафтну культуру. Серед їхніх праць щодо вивчення парків і садів маєтків України можна виділити ботанічний (більше уваги приділяє дендрофлорі) та екологічний (акцентує на потребі збереження довкілля) напрями.

Особливості садово-паркового мистецтва, історико-архітектурну та ботанічну складові польських маєтків Хмельниччини досліджує Л.Казімірова. В ії монографіï проаналізовано понад $5 о$ парків, пам'яток садово-паркового мистецтва, зокрема Ганнопільський, Малієвецький, Самчиківський парки ${ }^{57}$.

Співробітник державного дендрологічного парку «Тростянець» Т.Курбаль досліджує історію трьох старовинних парків родини Галаганів на Чернігівщині. Сокиринський, Дігтярівський і Тиницький парки належали цьому козацькому роду впродовж XVIII - початку XX ст., характерними рисами їх була природність. Поряд з історичними відомостями автор дуже професійно описує дендрофлору цих об’єктів, наголошуючи на потребі їх збереження та охорони ${ }^{58}$.

Отже, мистецтвознавчий напрям досліджень маєткової культури України, так само, як у радянський період, понині залишається одним із найкраще представлених. Дослідження щодо архітектури маєтків торкаються проблем біографій визначних зодчих, вивчення маєтків та їх стильового образу, садово-паркових комплексів як творів мистецтва, зокрема аналізу форм і композицій у парковому мистецтві, висвітлення принципів садово-паркового будівництва. Велику увагу мистецтвознавці й культурологи традиційно приділяють будівлям маєтків, інтер'єрам, декору, мистецьким колекціям. Архітектори переважно аналізують стилі маєткового будівництва та складають авторську періодизацію. Слід відзначити, що більшість праць архітектурного напряму наближені до історико-краєзнавчого (Н.Левкович, Н.Соснова, Л.Шевченко). Мистецтвознавці послуговуються різноманітними термінами («маєток», «садиба», «особняк», «резиденція», «палацово-парковий ансамбль», «палацово-парковий-комплекс»), які, утім, майже не отримують визначення в їхніх працях.

Природничий напрям представлений насамперед працями географів (історична й фізична географія, етнокультурне, антропогенне ландшафтознавство) та біологів (ботанічні аспекти садово-паркових комплексів). Репрезентанти цього напряму переважно акцентують увагу на садово-паркових ландшафтах, їх дендрофлорі. Слід відзначити

\footnotetext{
${ }_{55}$ Воловик В.М. Польські сільські етнокультурні ландшафти Поділля // Вісник ХНУ ім. В.Н.Каразіна: Серія: «Екологія». - №1147. - Вип.12. - Х., 2015. - С.41.

${ }^{56}$ Кравщуова І.В. Садово-паркові ландшафти як об'єкти рекреації і туризму // Природа Західного Полісся та прилеглих територій. - Вип.9. - Луцьк, 2012. - С.126; Ї̈ ж. Класифікація садово-паркових ландшафтів // Наукові записки Вінницького педуніверситету: Серія «Географія». - Вип.24. - Вінниця, 2012. - С.5.

${ }^{57}$ Казімірова Л.П. Парки - пам'ятки садово-паркового мистецтва Хмельницької області. - Кам'янець-Подільський, 2006. - $228 \mathrm{c}$.

${ }^{58}$ Курбаль Т.М. Парки родини Галаганів // Інтродукція рослин. - 2003. - №4. - С.147, 149.
} 
наявність праць, що поєднують ботанічні й культурно-мистецькі аспекти проблеми маєткових садово-паркових комплексів України. Проте подібних студій, які містять у собі міждисциплінарні компоненти природничих і гуманітарних наук, зокрема значну історико-краєзнавчу та культурологічну складові, на сьогодні обмаль.

Першорядним завданням для подальших досліджень $є$ чітке термінологічне визначення проблем маєткової культури України, адже наявна чимала кількість термінів, що використовуються сучасними дослідниками як синонімічні поняття, але насправді мають абсолютно різну етимологію.

Загалом сучасні праці вітчизняних фахівців сприяють поглибленню історико-архітектурних і природничих знань щодо маєткової культури України та залученню до наукового обігу низки забутих пам'яток палацової й садибно-паркової архітектури різних регіонів, що надає можливість створити цілісну історію розвитку маєтків нашої держави та їх культурного світу.

\section{REFERENCES}

1. Antoshko, M.O. (2018). Teatralne zhyttia Podilskoho kraiu kintsia XIX - pochatku XX st. Visnyk Natsionalnoi akademii kerivnykh kadriv kultury i mystetstv, 3, Mystetstvoznavstvo, 236-241. [in Ukrainian].

2. Bohdanov, V.O. (2008). Kriposni kapely i orkestry v Ukraini (na prykladi Volynskoi i Kyivskoi hubernii). Visnyk Kharkivskoi derzhavnoi akademii dyzainu i mystetstv, 13, 8-17. [in Ukrainian].

3. Boyko, O.H. \& Pohranichna, I.I. (2015). Palatsovo-parkovi ansambli Yakuba Kubitskoho na Volyni: Arkhitekturni osoblyvosti, propozytsii do restavratsii. Visnyk natsionalnoho universytetu «Lvivska politekhnika», 816, Arkhitektura, 177-185. [in Ukrainian].

4. Chechel, N.P. (2007). Ukrainskyi teatr pershoi polovyny XIX stolittia iak sotsiokulturnyi fenomen. Naukovi zapysky NaUKMA. Teoriia ta istoriia kultury, 62, 66-72. [in Ukrainian].

5. Hassanova, N. (1994). Palats u Sokyryntsiakh. Narodna tvorchist ta etnohrafiia, 2/3, 64-70. [in Ukrainian].

6. Izvarina, O.M. (2009). Kripatski ta amatorski teatry u muzychnomu pobuti mahnatskykh maietkiv v Ukraini. Naukovi zapysky Ternopilskoho natsionalnoho pedahobichnoho universytetu im. Volodymyra Hnatiuka ta Natsionalnoi muzychnoi akademii Ukrainy im. P.I.Chaikovskoho, 2(21), Mystetstvoznavstvo, 7-12. [in Ukrainian].

7. Izvarina, O.M. (2010). Maietkova kultura i muzychnyi pobut maietkiv pershoi polovyny XIX st. yak pidgruntia formuvannia opernoho mystetstva v Ukraini. Kultura i suchasnist, 2, 165-169. [in Ukrainian].

8. Kazimirova, L.P. (2006). Parky - pamiatky sadovo-parkovoho mystetstva Khmelnytskoi oblasti. Seriia «Terra in-cognita: Khmelnychchyna». Kamianets-Podilskyi. [in Ukrainian].

9. Khalaitsan, V.P. (2015). Palatsovo-parkovi kompleksy Yarmolynechchyny XVIII - pochatku XX st.: istoriia, problemy. Khmelnytski kraieznavchi studii, 5, 212-218. [in Ukrainian].

10. Khalaitsan, V.P. (2017). Mystetstvo maietkovoho parkobuduvannia Podillia XVIII - pochatku XX st.: evoliutsiia doslidnytskoi tradytsii. Visnyk Lvivskoi natsionalnoi akademii mystetstv, 34, 89-107. [in Ukrainian].

11. Khorosha, O.I. \& Smolyak, V.V. (2017). Istoryko-arkhitekturni osoblyvosti rozvytku palatsiv styliu klasytsyzm Skhidnoho Podillia kintsia XVIII - pochatku XIX st. Visnyk Natsionalnoho universytetu «Lvivska politekbnika», 878, Arkhitektura, 50-58. [in Ukrainian].

12. Khorosha, O.I. (2016). Doslidzhennia istoryko-arkhitekturnykh osoblyvostei Chornomynskoho palatsu XIX st. Skhidnoho Podillia. Nankovyi visnyk budivnytstva, 2, 94-98. [in Ukrainian].

13. Khorosha, O.I. (2017). Maietok Hrokholskykh-Mozhaiskykh - evoliutsiia palatsu vid istorychnoho stanovlennia do suchasnoi restavratsii. Naukovyi visnyk budivnytstva, 3, 33-38. [in Ukrainian].

14. Khorosha, O.I. (2018). Rozvytok palatsovoi arkhitektury styliu klasytsyzm na Skhidnomu Podilli. Suchasni problemy arkbitektury ta mistobuduvannia, 50, 88-98. [in Ukrainian].

15. Khorosha, O.I. (2019). Pryntsypy planuvannia parkiv palatsovo-parkovykh kompleksiv Vinnychchyny styliu klasytsyzm kintsia XVIII - pochatku XX st. Suchasni problemy arkbitektury ta mistobuduvannia, 53, 73-80. [in Ukrainian].

16. Kokhan, L.I. (2018). Rol maietkovoho mystetstva i pryvatnoi antrepryzy u stanovlenni ukrainskoho profesiinoho muzychno-dramatychnoho teatru. Chasopys Natsionalnoi muzychnoi akademii Ukrainy im. P.I.Chaikovskoho, 4(41), 37-47. [in Ukrainian].

17. Kovalchuk, N.P. (2006). Sadovo-parkove mystetstvo u pryvatnykh sadakh m. Lutska. Naukovyi visnyk NLTU Ukrainy, 3, 18-21. [in Ukrainian].

18. Kravtsova, I.V. (2012). Klasyf ikatsiia sadovo-parkovykh landshaftiv. Naukovi zapysky Vinnytskoho peduniversytetu, 24, Heohrafiia, 5-12. [in Ukrainian].

19. Kravtsova, I.V. (2012). Sadovo-parkovi landshafty iak obiekty rekreatsii i turyzmu. Pryroda Zakbidnoho Polissia ta pryleblykb terytorii, 9, 124-128. [in Ukrainian].

20. Kurach, S.M. (1995). Kolektsiia tvoriv mystetstva Halahaniv. Siverianskyi litopys, 5, 60-63. [in Ukrainian].

21. Levkovych, N.Ya. (2000). Palatsovi ta sadybno-parkovi ansambli Halychyny epokhy klasytsyzmu: Do pytannia periodyzatsii. Narodoznavchi zoshyty, 5, 900-905. [in Ukrainian].

22. Levkovych, N.Ya. (2002). Palatsovi ta sadybno-parkovi ansambli Halychyny kintsia XVIII - pershoi polovyny XIX st.: Do pytannia pobudovy ansambliu. Visnyk $N U$ «Lvivska politekhnika», 439, Arkhitektura, 246-250. [in Ukrainian].

23. Liubchenko, O.M. (2015). Arkhitekturno-kompozytsiine formuvannia parkovoho prostoru: pryntsypovi pidkhody. Ukrainska kultura: mynule, suchasne, shliakhy rozvytku, 21, 126-130. [in Ukrainian].

24. Mahei, A.S. (2019). Neohotychna sadyba v seli Kapustiany Vinnytskoi oblasti: sproba hipotetychnoi rekonstruktsii. Suchasni problemy arkhitektury ta mistobuduvannia, 55, 100-109. [in Ukrainian].

25. Malaniuk, V.Ya. (2006). Rozvytok klasytsystychnykh sadybno-parkovykh utvoren Kyivschyny kintsia XVIII-XIX st. Visnyk Natsionalnoho universytetu «Lvivska politekhnika», 568, Arkhitektura, 272-277. [in Ukrainian].

26. Matola, O.O. (2012). Diialnist amatorskykh teatralnykh oseredkiv u kulturi Ukrainy XIX st. Ukrainska kultura: mynule, suchasne, shliakby rozvytku, 18(2), 73-77. [in Ukrainian]. 
27. Matola, O.O. (2012). Stanovlennia amatorskoho muzychnoho teatru v Ukraini. Ukrainska kultura: mynule, suchasne, shliakhy rozvytku, 18(1), 36-40. [in Ukrainian].

28. Matola, O.O. (2014). Amatorska muzychno-teatralna kultura Ukrainy: istoriohrafiia doslidzhennia. Visnyk KNUKiM, 3, Mystetstvoznavstvo, 62-68. [in Ukrainian].

29. Mykhailyshyn, O.L. (2000). Palatsovo-parkovi ansambli Volyni 2-i polovyny XVIII-XIX st. Kyiv. [in Ukrainian].

30. Nykonenko, T.M. \& Hnatiuk, L.R. (2010). Do pytannia rekonstruktsii palatso-parkovoho ansambliu D.Troshchynskoho v Kaharlyku na Kyivshchyni na zasadakh filosofskoi kontseptsii “ekolohii dushi”. Suchasni problemy arkhitektury ta mistobuduvannia, 23, 60-68. [in Ukrainian].

31. Pobozhii, S.I. (2005). Z istorii ukrainskoho mystetstva. Sumy. [in Ukrainian].

32. Pobozhii, S.I. (2008). Pryvatni kolektsii yak sotsiokulturnyi fenomen. Suchasna kartyna svitu: pryroda, suspilstvo, liudyna, $274-$ 278. [in Ukrainian].

33. Pobozhii, S.I. (2009). Oleksii Krasovskyi: Materialy do biohrafii khudozhnyka. Sumskyi istoryko-arkhivnyi zhurnal, VI-VII, 133140. [in Ukrainian].

34. Pohranychna, I.I. (2016). Palatsovyi kompleks u s. Samchykakh Khmelnytskoi obl. - pryklad klasytsystychnoi yevropeiskoi arkhitektury kintsia XVIII - pochatku XIX st. Visnyk Natsionalnoho universytetu «Lvivska politekhnika», 856, Arkhitektura, 186190. [in Ukrainian].

35. Pohranychna, I.I. (2016). Vtracheni palatsovi kompleksy avtorstva Yakuba Kubytskoho na terytorii Ukrainy. Arkbitekturnyi Visnyk KNUBA, 10, 236-242. [in Ukrainian].

36. Publika, T.V. (2008). Rozvytok muzychnoho vykonavstva u panskykh maietkakh na terenakh Podillia XVIII - pochatku XIX st. Visnyk Prykarpatskoho universytetu, XII-XIII, Mystetstvoznavstvo, 237-240. [in Ukrainian].

37. Rodichkin, I.D. \& Rodichkina, O.I. (2005). Starovynni maietky Ukrainy. Kyiv: Mystetstvo. [in Ukrainian].

38. Ruban, V.V. (2010). Khudozhnyky i simeistvo Halahaniv. Sribne. [in Ukrainian].

39. Rychkov, P. \& Lushnikova, N. (2015). Natural materiality: water as an active element of the gardens by Denis Mcclair at Volhynia. Teka Komisii Architektury, Urbanistyki i Studiów Kraiobrazowych, 2, 52-62.

40. Rychkov, P. (2010). Zespół pałacowo-ogrodowy Lubomirskich w Równem w świetle planu Iana Iakuba Bourguignona z 1797 r. Biuletyn Historii Sztuki, 72(3), 335-349. [in Poland].

41. Shevchenko, L.S. (2001). Palatsovo-parkove budivnytstvo na Poltavshchyni u XVIII-XIX st.: istoriohrafichnyi aspekt. Ukrainska akademiia mystetstva: Doslidnytski ta naukovo-metodychni pratsi, 8, 211-217. [in Ukrainian].

42. Shevchenko, L.S. (2002). Istorychni peredumovy rozvytku palatsovo-parkovoho budivnytstva na Poltavshchyni u XVIII-XIX st. Arkheolohichnyi litopys Livoberezhnoi Ukrainy, 1,39-41 [in Ukrainian].

43. Shevchenko, L.S. (2003). Dvorianske hnizdo Muraviovykh-Apostoliv na Poltavshchyni. Abstracts of Papers 03: Poltava: arkbitektura, istoriia, mystetstvo, 33-39. Poltava. [in Ukrainian].

44. Shevchenko, L.S. (2009). Starovynni osobniaky Poltavy ta yikh znachennia v arkhitekturnomu rozvytkovi mista. Abstracts of Papers 09: Poltava: arkbitektura, istoriia, mystetstvo, 35-34. Poltava. [in Ukrainian].

45. Shevchenko, L.S. (2010). Osoblyvosti formuvannia palatsovoparkovoho ansambliu Kochubeiv u Dykantsi. Ukraynska akademiya mystetstva, 17, 172-183. [in Ukrainian].

46. Shevchenko, L.S. (2016). Starovynni prysadybni parky Poltavshchyny yak svoieridna forma syntezu mystetstv. Problemy rozvytku miskoho seredovyshcha, 1, 144-151 [in Ukrainian].

47. Sikorskaya, A.V. (2010). Muzykalnaia zhizn usadeb i aristokraticheskikh salonov v protsesse formirovaniia professionalizma $\mathrm{v}$ muzykalnoi kulture tsarskoi Rossii. Muzychne mystetstvo $i$ kultura: Naukovyi visnik Odeskoi derzhavnoi muzychnoi akademii im. A.V.Nezhdanovoï, 11, 239-247. [in Russian].

48. Sikorskaya, A.V. (2013). Liubitelskoe muzitsirovanie kak faktor formirovaniia intellektualnoi kulturnoi sredy v tsarskoi Rossii pervoi poloviny XIX v. Abstracts of Papers 13: Aktualnye problemy iskusstvovedeniia, filologii i kulturologii, 87-94. Novosibirsk. [in Russian].

49. Sikorskaya, A.V. (2014). Tvorcheskaia elita intellektualnykh muzykalnykh soobshchestv tsarskoi Rossii pervoi poloviny XIX v. Zhurnal nauchnykh publikatsii aspirantov $i$ doktorantov, 3, Iskusstvovedenie. Retrieved from: http://www.iurnal.org/articles/2014/iskus3.html [in Russian].

50. Smoliak, V.V. \& Khorosha, O.I. (2015). Doslidzhennia pamiatky arkhitektury kintsia XVIII - pochatku XIX st. - palatsu Tora Lanhe v seli Napadivka, Lypovetskoho raionu, Vinnytskoi oblasti. Suchasni problemy arkhitektury ta mistobuduvannia, 40, 137145. [in Ukrainian].

51. Smolynets, V. (2018). Utrymannia ta vidnovlennia krashchykh vzirtsiv maietkiv ta palatsiv Zakhidnoi Ukrainy. Visnyk Lvivskoho natsionalnoho abrarnoho universytetu, 19, Arkhitektura i silskohospodarske budivnytstvo, 151-154. [in Ukrainian].

52. Smyrnova, T.V. (2012). Problemy vyvchennia kulturnoi spadshchyny Volyni kintsia XVIII - pochatku XIX st. u spetsialnii literaturi. Ukrainska kultura: mynule, suchasne, shliakby rozvytku, 18(2), 41-45. [in Ukrainian].

53. Sosnova, N.S. (1996). Vplyv avstriiskoi kolonizatsii Halychyny na rozvytok sadybno-parkovykh kompleksiv. H.P.Petryshyn (Ed.). Nimetski kolonii Halychyny: istoriia, arkbitektura, kultura, 342-347. Lviv: Manuskrypt. [in Ukrainian].

54. Sosnova, N.S. (1998). Typolohiia sadybno-parkovykh kompleksiv Halychyny k. XVIII st. Visnyk Derzhavnoho universytetu «Lvivska politekbnika», 358, Arkhitektura, 285-290. [in Ukrainian].

55. Sosnova, N.S. (2000). Informatyvnist kadastrovykh kart (Do pytannia vyvchennia planuvalnykh struktur sadybno-parkovykh kompleksiv Halychyny ser. XVIII st.). Kartohrafiia ta istoriia Ukrainy, 252-258. Lviv; Kyiv; Niu-York: Kots M.P. [in Ukrainian].

56. Tymofiienko, V.I. \& Yeroshev, V.Yu. (1993). Ukrainska sadybna arkbitektura druboi polovyny XVIII st. - pershoi tretyny XIX st. Kyiv: NDITIAM. [in Ukrainian].

57. Tymofiienko, V.I. (1999). Zodchi Ukrainy kintsia XVIII - pochatku XX st.: biohrafichnyi dovidnyk. Kyiv: NDITIAM. [in Ukrainian].

58. Vecherskyi, V.V. (2014). Arkhitekturna spadshchyna Poltavshchyny. Ukrainska kultura, 6(1026), 26-31. [in Ukrainian].

59. Vecherskyi, V.V. (2014). Pamiatky Sribnoi zemli. Ukrainska kultura, 5(1025), 4-9, 22-27. [in Ukrainian].

60. Vecherskyi, V.V. (2015). Zamky ta fortetsi Ukrainy. Kyiv: Baltiia-Druk. [in Ukrainian].

61. Volosatykh, O. (2012). Muzychna i teatralna kultura maietkiv Pravoberezhnoi Ukrainy (persha polovyna XIX st.). Chasopys Natsionalnoi muzychnoi akademii Ukrainy im. P.I.Chaikovskoho, 4(17), 62-76. [in Ukrainian].

62. Volovyk, V. (2011). Istoriia doslidzhennia polskoi etnokultury u mistechkakh Podillia. Istoriia ukrainskoi heohrafii, 23, 32-36. [in Ukrainian].

63. Volovyk, V.M. (2015). Polski silski etnokulturni landshafty Podillia. Visnyk KhNU im. V.N.Karazina, 12(1147), Ekolohiia, 41-46. [in Ukrainian]. 


\author{
Mariia KAZMYRCHUK \\ Doctor of Historical Sciences (Dr. Hab. in History), Professor, \\ Docent at Department of Ethnology and Local History, \\ T.Shevchenko National University of Kyiv \\ (Kyiv, Ukraine), brungilda@ukr.net \\ ORCID: https://orcid.org/oooo-ooor-8877-4489
}

\author{
Nataliia MEKH \\ Doctor of Philological Sciences (Dr. Hab. in Philology), Professor, \\ Leading Research Fellow, \\ M.Rylskyi Institute for Art Studies, Folklore \\ and Ethnology NAS of Ukraine, \\ Ukrainian Ethnological Center \\ (Kyiv, Ukraine), mno_logos@ukr.net \\ ORCID: https://orcid.org/oooo-ooo2-5846-505X
}

\title{
The Manor Estate Culture of Ukraine in Modern Humanitarian and Natural Science Researches
}

\begin{abstract}
The aim of the article is to analyze the modern publications of representatives of the humanities and natural sciences on the manor estate culture of Ukraine at the end of 18th the beginning of 19th centuries. Methodology. General scientific principles, method of historiographic analysis and problem-chronological method are applied in the research. A scientific novelty of the article is consisted in the fact that current researches of the manor estate culture of Ukraine made by representatives of the art studies tendency and the natural sciences tendency have not been overviewed hitherto. Conclusion. The art studies tendency in the manor estate culture of Ukraine researches is the best represented as it was in the Soviet time. Studies of the architecture of manor estates deal with famous architects biographies, problems of the manor estate style patterns, there landscape complexes are examined as artworks, in particular, forms and composition in the landscape art are analyzed, principles of the landscape development are highlighted. Art critics and culturologists traditionally focus close attention on manor estate buildings, interiors and art collections. Architects mostly analyze manor estate styles and make authors periodizations. It has to be emphasized that the most of researches made by representatives of this tendency are very close to works of scholars belong to the local historian tendency. The natural science tendency is represented, first of all, by publications of geographers (the historical and physical geography, the ethnocultural and anthropogenic landscape studies) and biologists (the botanic aspects of landscape complexes). These researchers accentuate on landscapes and their dendroflora. Current works of domestic scholars facilitate deepening historical, architectural and natural knowledge on the manor estate culture of Ukraine and introducing lost sites of palace and landscape architecture from different regions into scientific use. All of this gives an opportunity to reconstruct the history of manor estate of Ukraine and their cultural world.
\end{abstract}

Keywords: manor houses, castles, villas, restoration, architectural monument, reconstruction, landscape complex. 